\title{
Accounting Treatment for Heritage Assets: A Case Study on Management of Pari Temple
}

\author{
Heri Widodo*, Nur Ravita Hanun, Retno Wulandari
}

\begin{abstract}
:
Research Aims: This research is conducted to find out how the accounting treatment of the Heritage Asset, Pari temple, how the assets are recognized, recorded and reported in the financial statements using a case study viewpoint.

Design/Methodology/Approach: The Researchers collected the research data in three phases; first, the Researcher interviewed informants or sources from relevant department or manager of Pari temple, namely the Balai Pelestarian Cagar Budaya (BPCB) Jawa Timur, second, the researcher checked documents of the Heritage Assets Pari temple, how it's recognized, as what, recorded, until now the value of Heritage Assets is, and the last data searching. Methods of data analysis in research is divided into three stages, first, data reduction, data selection, concentration, attention, abstraction and transforming the raw data from the field, second, the data display, presents data in the narrative and tables form to explain the phenomenon under study and the last is the conclusion.

Timur is that Pari temple is recorded as a plant asset, and Pari temple is deliberate without value, so the Heritage Assets can not be traded. The amount of this recording conforms with based government accounting standards (PSAP) no. 07 the year 2010 statement no 69 that Heritage Assets must be recorded in the number of units without value.

Theoretical contribution/Originality: The research contributes to find out how the accounting treatment of the Heritage Assets Pari temple

Practitioner/Policy implication: Heritage assets are a material cultural heritage in the form of cultural heritage objects, cultural heritage buildings, cultural heritage structures, cultural heritage sites and cultural heritage areas on land or in water that needs to be preserved because they have essential values for history, science, education, religion, or culture through the determination process. Research limitation/Implication: The limitation of this research is that it has only a few informants since, in order to improve the effectiveness of research time, the researcher focuses more on the accounting treatment for Pari Temple as heritage assets.
\end{abstract}

AFFILIATION:

*CORRESPONDENCE:

heriwidodo@umsida.ac.id

THIS ARTICLE IS AVALILABLE IN:

http://journal.umy.ac.id/index.php/ai

DOI: 10.18196/jai.2101138

\section{CITATION:}

Widodo, H., Hanun, N. R., \& Wulandari, R. (2020). Accounting Treatment for Heritage Assets: A Case Study on Management of Pari Temple. Journal of Accounting and Investment, 21(1), 74-89.

\section{ARTICLE HISTORY}

Received:

08 May 2019

Reviewed:

$18 \mathrm{Jul} 2019$

Revised:

12 Aug 2019

Accepted:

01 Jan 2020

Keywords: Heritage Assets; Recognition; Recording; Assessment; Pari temple; BPCB Jawa Timur

\section{Introduction}

The heritage building is one of the historic buildings, which is a heritage asset for the government. Research on heritage assets has been frequently conducted abroad, but not in Indonesia. This is because there are still a lot of confusing things from heritage assets, especially the problem of the most appropriate accounting treatment for heritage 


\section{Widodo, Hanun, \& Wulandari \\ Accounting Treatment for Heritage Assets: A Case Study on Management of Pari Temple}

assets. Accounting for heritage assets is one of the issues that is still debatable. Many definitions describe the nature of heritage assets. However, until now, there is still no definitive legal definition regarding heritage assets.

Heritage assets are unique assets because these assets have a variety of ways of acquiring, not only through development but also purchases, donations, inheritance, booty, or confiscation. The government often has difficulty in monitoring financial management in the accountability of various potential Heritage assets. The obstacles are in the central government policy, which does not require local governments to present heritage assets in the Financial Position Report. This research is considered important because it can provide clarity about accounting standards for heritage assets that should be applied by Pari Temple.

Heritage assets are assets with artistic, scientific, technological, geophysical, or environmental qualities that are held and maintained to contribute ideologically to science and culture. Heritage assets consist of several types including heritage buildings, monuments, archeology cycles, conservation areas, and artwork (Barton, 2000). Heritage assets are resources concerning which each country establish a regulatory system designed to protect them, as common public goods (Aversano, 2016). At the international level, UNESCO (United Nations Educational, Scientific and Cultural Organization) is the organization set up by the United Nations which has the task to identify, protect, and safeguard the cultural and natural heritage around the world in order to pass to the future generations the heritage of the past.

Heritage assets are one of the assets protected by the state. These assets are vital for a nation because heritage assets are a manifestation of culture, history and identity for the country itself. Not only the economic value that can be generated from these assets but also the values contained in them such as the values of art, culture, history, education, knowledge and others, must be preserved and maintained for sustainability (Agustini, 2011).

The issue of heritage assets in the recognition stage is that there is still debate over the classification of heritage assets as assets or liabilities in the balance sheet. Some national and international accounting standards councils (for example, IPSASB, Australia AASB, New Zealand FRSAB, United Kingdom ASB and PSAP) agree that Heritage assets are assets included in the balance sheet to improve the quality of the information reported (Agustini, 2011; Aversano, 2016). Heritage assets cannot be described as financial assets and do not meet the requirements to be recognized as assets. Heritage assets are not assets, either in terms of conventional accounting or in conversion terms. It would be more appropriate to clarify these heritage assets as obligations or only as facilities and present separately.

The next problem is the stage of assessing heritage assets, each country has its valuation method following the conditions and situations in each state, and for these assets, national and international accounting standards do not yet have a rule for valuation methods of heritage assets that can be used universally or overall (Agustini, 2011). 


\section{Widodo, Hanun, \& Wulandari \\ Accounting Treatment for Heritage Assets: A Case Study on Management of Pari Temple}

Problems with heritage assets are also found in disclosures. This stage is the most crucial because, as managers and maintainers of heritage assets, the government must present financial statements for transparency and accountability for the benefits they obtain from heritage assets (Barton, 2000). Besides, disclosures are made to see the performance of the government on heritage assets such as income and expenses incurred for heritage assets (Ouda, 2014).

The related research was tough to be found due to limited information resources the notion of "taboo" mixed history with economic matters for some historians and archeologists in Indonesia (Anggraini, 2014). It can be concluded that at the stage of recognition of heritage assets, the Indonesian government should treat the same between non-operational heritage assets and operational Heritage assets, which are recognized as fixed assets in financial statements (Agustini, 2011).

Another research was conducted in New Zealand. In that study, Wild criticized the political ideology and practice of the NPM (New Public Management). His assumption that private sector financial statements are based on GAAP can be applied to public and non-profit benefits such as HCA (Heritage, Cultural, and Community Assets). He proposed models of alternative reporting based on a set of cultures rather than economic values for reporting HCA (Wild, 2013).

From the various data obtained above, it can be concluded that heritage assets are fixed assets with an age that cannot be determined which are owned or controlled by the government so that they must be protected because they have artistic, cultural, Heritage, educational, knowledge and unique characteristics in them.

This study focuses on how the accounting treatment for heritage assets in Indonesia explained in recognition, valuation, presentation, and disclosure of financial statements. This study uses a qualitative method with a phenomenological approach.

Pari Temple was chosen as the object of research because Pari temple is one of the heritage assets in Indonesia, one of the cultural reserves that can be said to be intact until now. In addition, Pari temple has a unique architecture in Pari Temple consisting of temple feet, temple bodies, temple chambers, and temple roofs. Overall made of bricks, there are only a few parts made of andesite. The foot of the temple consists of two parts; the first part has four squares, has two entrances to the chamber with the north and south-north direction. Such things have never been found in East Javanese architecture. The foot of the second temple is square with a length of $10 \mathrm{~m}$ and a width of $10 \mathrm{~m}$ with a height of $1.95 \mathrm{~m}$. On one side there are stairs going up to the booth, BP3 East Java has renovated this staircase. The temple body is square while the entrance of the temple is rectangular, and Pari temple is also the center of tourism in Sidoarjo. Pari Temple is located in Pari Village, Porong District, Sidoarjo Regency.

The research of Wulandari and Utama (2016) explained the Anjuk Ladang Museum would recognize the collection/finding as a historical asset after obtaining validation from the East Java BPCB. Manager of the Anjuk Ladang Museum unfulfilled the 
standards government No. 07 (PSAP) because it has no presentation and disclosure of heritage assets in the CALK report. Meanwhile, Darmawan, Yadnyana, and Sudana (2017) explain that disclosure of Semarajaya Museum collection objects in the balance sheet has been presented under PSAP No. 07 but has not been disclosed in CALK.

This study is based on research results from Wulandarai and Utama (2016) and Darmawan, Yadnyana, and Sudana (2017). Thus, the formulation of the problem to be answered in this study is as follows: how the accounting treatment for heritage assets in Indonesia explained in recognition, valuation, presentation and disclosure of financial statements.

The results of this study are expected to contribute in the form of suggestions and inputs related to the heritage assets. Besides, the results of this study are expected to Improving the quality of financial statements to achieve transparency and reliability.

\section{Literature Review and Focus of Study}

Accounting can be defined in terms of accounting as art, science; technology can even be determined based on other perspectives. One of them is accounting can be defined as a process. Accounting is a process of identifying, measuring, recording and reporting economic transactions from an organization or entity for the occurrence of information in the context of decision making (Halim, 2014).

Accounting is also a communication tool that can be utilized by interested parties in making policies. The parties involved in the use of information are internal parties and external parties. Internal parties are organizational managers, while external parties are shareholders, creditors, and the government.

Heritage assets are economic resources that are controlled and/or owned by the government as a result of past events and from commercial and/or social benefits in the future are expected to be obtained, both by the government and society and can be measured in units of money, including sources non-financial resources needed to provide public clothing for the general public and resources maintained for Heritage and cultural reasons (PSAP, 2010).

An asset is an economic sacrifice made by a company or entity to gain profit in the future, from several definitions of the asset, some characteristics of the asset can be deduced, namely:

a. Assets are resources controlled or owned by an entity;

b. Controlled by entity

c. Assets have economic benefits in the future and

d. the result of past transactions or events.

The word "heritage" is generically referred to as resulting "from the past," while the term "asset" refers to goods, activities, or resources (Aversano, 2016). Heritage assets 


\section{Widodo, Hanun, \& Wulandari \\ Accounting Treatment for Heritage Assets: A Case Study on Management of Pari Temple}

are one of the assets of the public sector that experiences a diversity of concepts, terminology. And classification. Some authors refer to Heritage assets as community assets. Although not all community assets are heritage assets (Pallot, 1992). Many definitions describe Heritage assets, which makes the different criteria that will be used in determining the definition of heritage assets. Just as the criteria used to regulate (property, plant and equipment) state that some assets are described as Heritage assets because of their culture, environmental significance or history (IPSAS, 2010). "Some assets remain explained as heritage assets due to cultural, environmental and Heritage interests. Examples of heritage assets are Heritage buildings, monuments, archaeological sites such as temples and work of art " (PSAP, 2010).

SAP in PSAP Number 07 of 2010 the characteristics of heritage assets are as follows:

a. Cultural, environmental, educational, and Heritage values cannot be adequately symbolized by financial values based on market prices.

b. Regulations and applicable laws prohibit or strictly limit their release for sale.

c. It is not easy to replace, and the value will continue to increase during the run even though the physical condition decreases.

d. It is difficult to estimate the useful life. In some cases, it can reach several years.

In contrast to opinions expressing that heritage assets have several aspects that distinguish them from other assets (Aversano, 2012), including:

a. Cultural, environmental, educational and Heritage values contained in assets are not completely reflected in monetary terms.

b. There are difficulties in defining book values based on market prices that fully reflect the importance of art, culture, environment, education, and history.

c. There are legal restrictions and restrictions according to the law for sales problems.

d. The existence of assets is irreplaceable, and the value of assets makes it possible to increase over time, even though asset conditions deteriorate.

e. There are difficulties in estimating the unlimited useful life, and in some cases, it cannot yet be defined.

f. These assets are protected, maintained and maintained,

From some characteristics of heritage assets, it can be concluded that there are several characteristics of fixed assets that we cannot find in the features of heritage assets. Because heritage assets have a broad enough scope, before we determine the price, we must know the use of heritage assets themselves. In fixed assets, there is a charge attached to the object so that the young determine how much rupiah is contained in the fixed asset. The use of several methods can be used to assess the value of the rupiah value of the fixed asset. But it is not the case with heritage assets; the housing that is attached is very difficult to trace, so it requires special treatment of heritage assets. The use of heritage assets and the time of acquiring heritage assets will affect the treatment of asset recognition in financial statements. Because the boarding house will also change the attributes that will be displayed in the financial statements.

The use of heritage assets will affect the measurement and assessment of heritage assets themselves. Although an item in a historic asset meets the criteria for recognizing 
fixed assets, it does not mean that all heritage assets must be recognized in the financial statements. Several aspects need to be considered in understanding heritage assets. To facilitate the recognition of heritage assets consists of two types, namely:

a. Operational Heritage Assets or Heritage assets for Operational Activities

This historic asset is a type of asset that has a dual function; in addition to being Heritage evidence, this asset also plays a role as a place of daily government operations. For example, it is used as an office. This type of historic asset needs to be capitalized and recorded in the balance sheet as a fixed asset (PSAP, 2010).

b. Non-operational Heritage Assets

Non-operational Heritage Assets are purely used assets because of their aesthetic value and Heritage value. Unlike the case with heritage assets used for operational activities, this asset does not have multiple benefits. In America, this type of asset is called heritage assets, while assets that are used for operational activities are called multi-use heritage assets.

Non-operational types of heritage assets can be divided into three types, namely:

a. Land and Heritage Buildings (Cultural Heritage Assets)

b. Artwork (Collection of Heritage Assets)

c. Archaeological Sites or Landscape (Natural Heritage Assets)

In Indonesia, this type of asset does not need to be recognized in the balance sheet, but it is sufficient to be reported in the Notes to the Financial Report (PSAP, 2010). Recognition of heritage assets included in non-operational heritage assets. However, the type of non-operational heritage assets that can be recognized in the balance sheet are the kinds of land assets and Heritage buildings obtained in the current period. This is in line with the recognition of heritage assets that can be recognized as fixed assets in the balance sheet if they have a reliable board. In determining a reliable boarding house, a proof is needed to show what board is attached to an item. So far, the reasons for not recognizing non-operational heritage assets are complicated to obtain reliable values; this is because:

a. No data or records or evidence shows the acquisition price so that the government entity is difficult to determine the boarding that is attached to the object or historic asset that is old. Reliability to determine the boarding house is to know the accuracy in estimating the price or value of the historic asset.

b. If we find it difficult to assess the reliability of importance on these objects, Heritage assets cannot be recorded on the balance sheet.

c. Consideration of costs and benefits to obtain an estimate of the fair value of Heritage assets acquired in the previous period. It is not easy to determine the cost of the object attached to an object, especially when it is associated with the Heritage value possessed. It takes a long time, and prices are high. Capitalized Heritage values are also less useful and less comparable with other entities because of the inability to measure Heritage assets that have unique attributes to be compared with reliable boarding. 
In Indonesia, Heritage assets are categorized into fixed assets, but for procedures for recognizing heritage assets, they have their own rules (PSAP, 2010), namely:

a. The government may have many Heritage assets acquired over the years and with a variety of means including purchases, donations, inheritance, booty, or confiscation. These assets are rarely mastered due to reasons for their ability to generate cash inflows and will have social and legal problems when using them for this purpose.

b. Costs for obtaining construction, upgrading, reconstruction must be charged as expenditure for the year the expenditure is incurred. These costs include all expenses that are incurred to make the historic asset in the condition and location in the current period.

Regional assets or goods, including buildings other than buildings, are monuments (Yusuf, 2010). Monuments are buildings or places that have heritage value and the arena is maintained and protected by the state. Then recording assets must be complete because the data will be used throughout the period. As with other input forms, the input form for recording assets in the form of monuments is not much different, especially regarding the source of data needed, namely the name of the activity and origin of the account in the budget implementation document (Wulandari \& Utama, 2016). This document is the basis that an action is worth noting in the book of goods or assets. Other data needed such as the type of monument in the form of historic buildings, memorials, temples, other historic buildings, monument signs, and signs. From the input data, it needs to be moved into the output data as the information responsibility, where later this data can be given to other parties (stakeholders), both in the framework of records or business administration to be recorded in the financial statements and balance sheets and Notes to the Financial Statements (CALK) (Darmawan, Yadnyana, \& Sudana, 2017).

Assessment is a process for determining economic value or object, post, or element (Statement of Financial Accounting Concept No.5). Assessment is usually used to designate the process of determining the amount of rupiah that must be attached to each element or post of a statement of memories during a presentation. The purpose of asset valuation is to represent the attributes of asset posts related to the purpose of financial statements using the appropriate valuation base.

Indonesia does not yet have standards or rules for assessing heritage assets. Heritage assets have different valuation models in each country because they are adapted to the conditions and situations in each state.

Assessment models include:

a. Institutions must use a revaluation model for all heritage assets and measure these assets at fair value. This match to GAAP. After the fair value of the asset has been determined, the asset must be revalued based on a 3-year valuation cycle. The fair value must be found on the current market selling rights for the same or similar assets. However, many types of heritage assets have unique properties, so they cannot be measured based on market selling prices. Therefore, the fair value of an asset can be estimated using a depreciated income or replacement approach. Assets 
can be valued at replacement costs with the same and not identical assets but provide the same benefits (Accounting Policy Act 2009).

b. Heritage assets are obtained with no nominal fees or fees; these assets must be measured at fair value on the date of acquisition. In determining the fair value of Heritage assets obtained from non-exchange transactions, an entity must apply the principles of the determination of fair value. After that, the entity can choose to adopt either a revaluation model or a cost model following Generally Recognised Accounting Practice (GRAP) 103 (GRAP, 2012).

c. Revaluation is not allowed because SAP adheres to the valuation of assets based on acquisition costs or exchange prices. In the event of a significant price change, the government can revaluate the assets held so that the current value of government fixed assets reflects the current fair value (PSAP, 2010).

Disclosure is the presentation of information in the form of financial reports as the final step in the accounting process. Before knowing how to disclose and present heritage assets, you should first know the types of financial statements where the heritage assets will be disclosed and presented. The basic financial statements that must be compiled and presented by the reporting entity according to SAP Cash-Based Towards Accrual (Halim, 2014; Safitri \& Indriani, 2017), namely as follows:

a. Budget Realization Report (LRA)

b. Balance Sheet

c. Cash Flow Statement

d. Notes to the Financial Statements (CALK)

Meanwhile, Accrual-Based SAP requires reporting entities to compile and present seven necessary financial reports that are divided into two types of reporting, namely accrualbased financial reporting, reporting on the implementation of cash-based budgets, and notes on a financial statement (Catatan Atas Laporan Keuangan/ CALK).

A. Financial reporting consists of:

1. Balance Sheet

2. Operational Report (OP)

3. Cash Flow Statement

4. Reports of Changes in Equity (LPE)

B. The budget implementation report consists of:

1. Report on Cash-Based Budget Realization

2. 2. Report on Changes in Budget Balance (SAL)

CALK is a report detail or posts in the budget implementation report and financial report and is an integral report from the two reports. Presentation and disclosure of heritage assets, Heritage assets revealed in the Notes to Financial Statements (CALK) alone without value, except for several heritage assets that provide other potential benefits to the government in addition to its Heritage value, for example, buildings for office space, these principles will be applied the same as other fixed assets. Heritage assets included in the group will be included in the balance sheet. Heritage assets must be presented in 
the form of units, for example, the number of units of a collection owned or the number of groups of monuments in the Notes to Financial Statements with no value. This means that this statement does not require presenting Heritage assets (Heritage Assets) on the balance sheet but must be disclosed in Notes to Financial Statements (PSAP, 2010).

Measurement is an essential part of a scientific investigation, which is also a process of giving numbers or labels to the unit of analysis to present concept attributes, while attributes are something that is attached to an object that describes the nature or characteristics contained in the object (Suwardjono, 2010). These measurements make the data produced more informative and therefore more useful. This measurement theory is needed in carrying out economic assessments of heritage assets that have unique time dimensions and intrinsic elements. The sizes used in the study are:

1. Size obtained directly and indirectly, namely:

a. Direct or main size is a real measure of an object or attribute that is owned. This measure can be attributed to heritage assets that have an active market.

b. Indirect or secondary measures come from transformations of many numbers that reflect the direct size of several objects or intrinsic attributes of indirect action. This measure can be attributed to heritage assets that have no active market and that have Heritage or artistic uniqueness.

2. Size is related to the dimension of time when the measurement was made, namely:

a. Size of the past

1) Size of retrospective past

2) Size of contemporary past

3) Size of prospective past

b. Current size

1) Contemporary contemporary sizes

2) Prospective present size

3) Future size

All future sizes are prospective.

3. Measurement can also be:

c. Fundamental measurement

Where a number can be given to a trait according to its reference to natural law and does not depend on the measurement of other variables.

d. Derivative measurements It depends on the measurement of two or more quantities and the existence of an empirical theory that has been verified and connects specific characteristics with other characteristics.

The measurement theory can be associated with economic valuation methods of heritage assets, where the selection of measurement theory is applied according to the nature and inherent conditions of unique heritage assets. 


\section{Widodo, Hanun, \& Wulandari \\ Accounting Treatment for Heritage Assets: A Case Study on Management of Pari Temple}

Accounting for heritage assets is regulated in the Government Accounting Standards Guidelines (PSAP) No. 07 of 2010. Based on the point of view, heritage assets are not allowed to adopt revaluation, but adhere to the valuation of assets based on acquisition costs or exchange prices. In the event of a significant price change, the government may revaluate the assets held so that the current value of government fixed assets reflects the current fair value.

When viewed in terms of the presentation and disclosures in financial statements, Heritage assets are disclosed in the Notes to Financial Statements (CALK) without value, except for some heritage assets that provide other potential benefits to the government in addition to its Heritage value, for example, office buildings. For the case of this type of asset, asset valuation is based on the same principles as other fixed assets. Heritage assets included in the group will be included in the balance sheet (PSAP, 2010).

\section{Research Method}

Based on the description of the theoretical foundation that has been explained. The process begins by identifying the definitions of heritage assets first. After knowing the meaning of assets, the most appropriate alternative assessment methods can be determined. The final stage will be obtained how heritage assets should be presented in the financial statements.

A series of processes above is expected to produce useful information for external and internal parties. This information is a manifestation of the responsibility of the entity managing heritage assets to both parties. External parties refer to the community as taxpayers, while internal parties refer to the regional government and the central government.

The data in this study consist of both primary and secondary data. Primary data is obtained directly from field research. The data is in the form of interviews with research informants, namely the Financial management division and BMN (Barang Milik Negara) management division of Balai Pelestarian Cagar Budaya, East Java. The interview was conducted at BPCB East Java with Mr. HY as part of the Financial Manager and Mrs. HS as the BMN Management Section in the General Unit. This research performs triangulation source of information to examine data validity by utilizing something else to compare the results of an interview with research object.

To get the primary data, researchers used the interview method. Interviews are conducted to produce in-depth qualitative data. The method of interviewing conducted by researchers is structured and unstructured interviews. A structured interview is an interview in which the interviewer defines the problem and the questions that will be asked (Moleong, 1993). Whereas unstructured interviews are used to obtain in-depth information through sources that are deep in the situation and more aware of the information that is being needed by the interviewer. To get secondary data, researchers 
used document analysis methods. The document is obtained directly from the relevant agency.

Considering the data collected in this study is in the form of qualitative data, the data validation test carried out is more emphasized in the qualitative data validation test. The steps taken in developing research data validation are:

1. Source Triangulation

Triangulation of sources tests data credibility by checking data that has been obtained through several sources. In this study, the authors confirmed to the regional coordinator regarding the accounting treatment for heritage assets (Sugiyono, 2009).

2. Triangulation Test

Triangulation of data by combining interviews and documentation. Triangulation of this test is carried out by documenting the accounting treatment for heritage assets at Pari temple and interviewing the interested parties directly, and the party is the Center for Preservation of Cultural Heritage (Moleong, 1993). Triangulation of this test is carried out by means of documentation of the accounting treatment for heritage assets in Pari Temple and interviews with relevant parties, which is BPCB East Java.

In general, the method of data analysis in qualitative research is divided into two parts; first is data reduction, and the second is data display. If described, the method of data analysis in qualitative research is as follows:

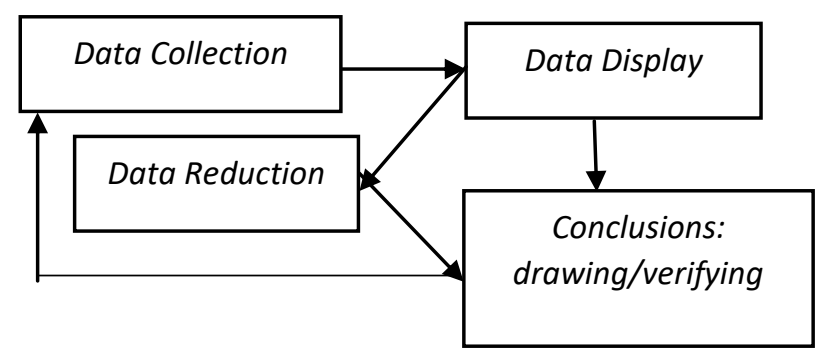

Figure 1 Data Analysis Method

Source: Sugiyono (2009)

\section{Result and Discussion}

Heritage assets in the Management Perspective

Based on the East Java BPCB as the manager of Pari temple, the characteristics of Heritage assets that have value in the course of this country's history, everything in the form of objects, buildings, sites, areas included in the category of cultural heritage will be included as a category of heritage assets. Heritage assets are included in the group of assets because they have something of value because there is the value attached to the object. 


\section{Widodo, Hanun, \& Wulandari \\ Accounting Treatment for Heritage Assets: A Case Study on Management of Pari Temple}

In recognition of a historic asset, it requires a certain budget that will be charged to the routine service budget related to the return on discovery services. The fee provided is based on the authenticity and condition of the asset. This is regulated in the Law of the Republic of Indonesia No. 11 of 2010 concerning Cultural Heritage.

Recognition of the Heritage Assets of Pari Temple

Based on the East Java BPCB as the center of the East Java Cultural Heritage that for the recognition of all Heritage assets found, it will still be recognized as a regional asset. Heritage assets are indeed the right to be recognized in the asset class; in this study, the temple Pari's heritage assets. The Heritage assets of Pari Temple include buildings and buildings which are Heritage monuments. Besides being able to generate economic benefits in the future, heritage assets are also something that is owned by an entity. In contrast to liabilities which in the future will have obligations that must be fulfilled, namely the obligation to deliver goods or services to other parties.

\section{Listing of Pari's Heritage Assets}

Based on the results of the analysis with the speakers at BPCB East Java as the center of the East Java Cultural Heritage that the BPCB East Java only records the Semester User Proxy Report, in the report heritage assets are divided into three types, namely equipment and machinery, buildings and buildings, and other fixed assets, in the report heritage assets are recorded in units. This is under SAP No. 07 of 2010 concerning Government Accounting Standards which mandate to present heritage assets in the Notes to Financial Statements.

\section{Pari Temple Heritage Assets Assessment}

Based on the results of the analysis with the speakers at BPCB East Java as the center of East Java Cultural Heritage, the valuation of Pari Temple as a National Asset is expected to be used as a guideline for assessing other Heritage objects, but until now the study has not found a light and is still being evaluated. Right for heritage assets. In this statement, in evaluating the heritage assets of BPCB East Java as the center of the East Java Cultural Heritage, only recorded them in the form of units and invaluable.

The difficulty in assessing Pari temple as a historic asset can be attributed to the meaning of heritage assets. Heritage assets are inheritance, cultural properties in the form of cultural heritage objects, cultural heritage buildings, cultural heritage structures, cultural heritage sites and cultural heritage areas on land and/or in water which need to be preserved because they have essential values for history, science, education, religion, and/or culture through the determination process. This meaning indicates that heritage assets are not directly related to economic aspects, so it is not easy to assess the amount of rupiah attached to heritage assets including the Pari Temple (Dhani, Husaini, \& Abdullah, 2017). 
Pari temple Presentations and Disclosures in Financial Reports
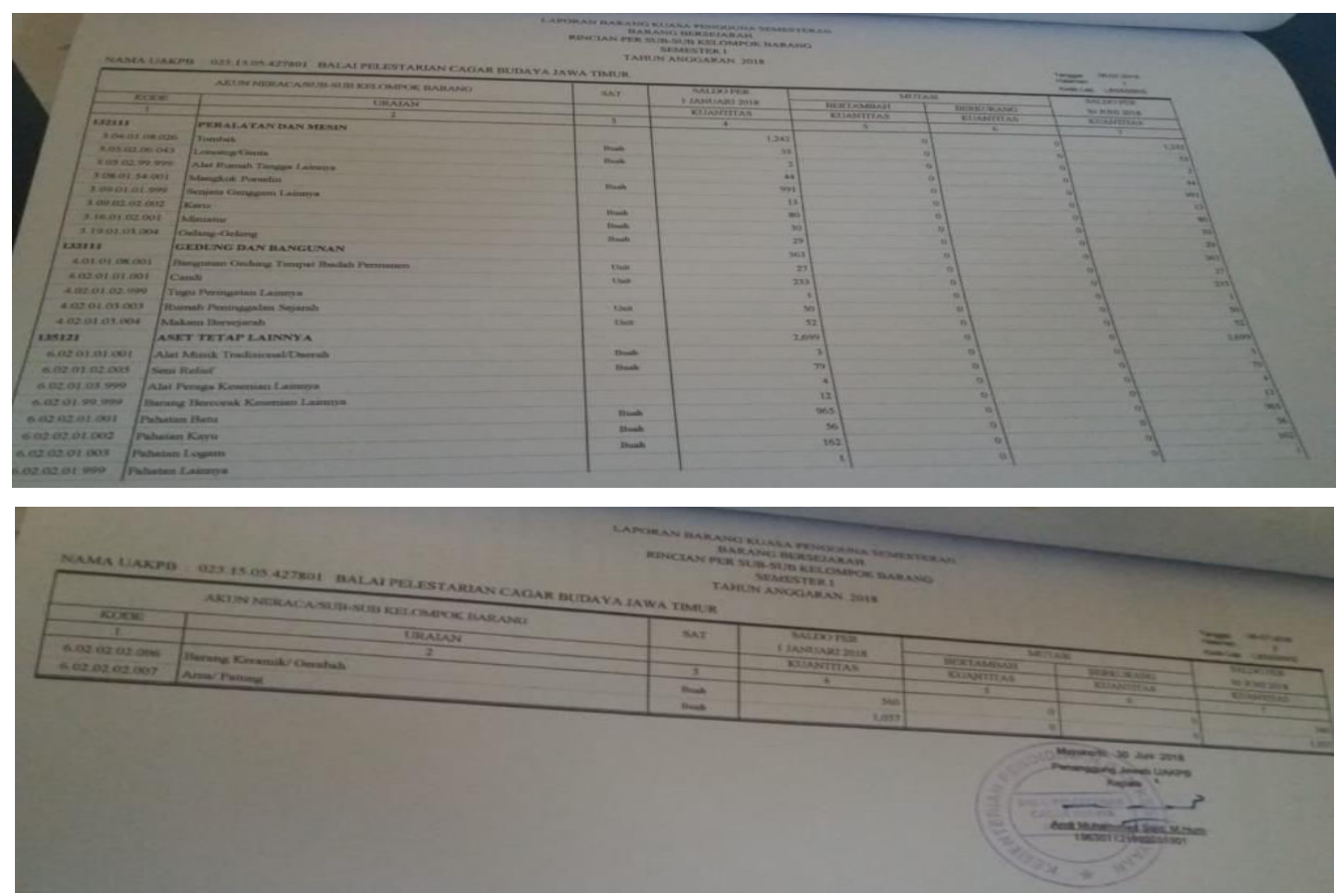

Figure 2 Heritage Asset Presentation

Source: Balai Pelestarian Cagar Budaya (BPCB) East Java 2018

Based on the results of analysis from BPCB East Java as the center of East Java Cultural Heritage, the presentation of Pari Temple was recorded in the form of a unit and was invaluable. In the BMN referral report and Notes to the Financial Statements, BPCB East Java records all Heritage assets in East Java.

According to PSAP 07 - The Government is not required to present heritage assets in the Financial Position Report, but these assets must be disclosed in the Notes to the Financial Statements. Following its obligations, the presentation and disclosure made by BPCB East Java are stated in PP 71 N0. 07 concerning reporting Heritage assets on CaLK, so that heritage assets are also reported in the presentation of Notes to Financial Statements.

\section{Measurement of Pari's Heritage Assets}

Heritage assets are assets that are owned or controlled by the government because applicable regulations must protect the age and condition of these heritage assets from all kinds of actions that can damage the asset. Measurements in accounting indicate the process of determining the amount of rupiah in the object at the time of acquisition. The amount of the rupiah will be a measure of the entity's assets and will become an accounting material called boarding. Measurements can be considered if there is an exchange transaction with proof of asset purchase that identifies the cost. 


\section{Widodo, Hanun, \& Wulandari \\ Accounting Treatment for Heritage Assets: A Case Study on Management of Pari Temple}

Based on the results of the analysis obtained from the BPCB of East Java as the East Java Cultural Heritage Center, the measurement of Pari temple's heritage assets is still a problem related to the accounting treatment. Other Heritage assets, whether in the form of museum items or other heritage assets obtained in the current period, can be known for their cost. However, specifically for Heritage assets in the way of monuments, assessments have never been made.

Pari temple measurements are assets obtained by transactions, such as buying and exchanging can be measured by the acquisition cost of the asset. Goods received by grants usually clearly have significant economic benefits derived by the entity without a substantial value, in other words, the building and land acquired by the entity are examples of acquiring assets without a price. Research by Basnan, Salleh, Ahmad, Harun, and Upawi (2015) explains that the transition from cash to accrual-based accounting has raised several issues, particularly relating to assets that have special characteristics and are unique such as heritage assets. These assets pose considerable challenges, especially in terms of the recognition and measurement of the assets. Despite the challenges, these assets should be accounted for and reported accurately according to their specific characteristics and unique nature so that stakeholders will get a comprehensive and accurate picture of the financial values of the assets and financial position of the government as a whole. Thus, the challenges such as those described in this paper should be given serious attention to facilitate a proper and accurate accounting treatment and reporting for the assets and to ensure the successful implementation of accrual accounting by the Federal Government of Malaysia.

According to Biondi and Lapsley (2014), the investigation reveals that the first level, or minimal level, of transparency, is unlikely to be achieved for public organizations with heritage assets, mainly due to deep-seated, pernicious problems of asset recognition and valuation. Recent changes in accounting directives for heritage assets held by the government, local authorities and charities in the UK required their attention in the financial statements and the measurement of their economic value. Subsequently, numerous sales of heritage assets by local authorities emerged. In those three countries, it is clear that the comparability of the financial statements between countries was not a concern of policy-makers and comparability between cities within each country not a matter of preparers.

\section{Conclusion}

Heritage assets are a material cultural heritage in the form of cultural heritage objects, cultural heritage buildings, cultural heritage structures, cultural heritage sites and cultural heritage areas on land and/or in water that need to be preserved because they have important values for history, science, education, religion, and / or culture through the determination process.

The BPCB Trowulan East Java recognizes heritage assets as assets and is listed in the asset list on the management and accounting reports of state property (SIMAK MBN), 


\section{Widodo, Hanun, \& Wulandari \\ Accounting Treatment for Heritage Assets: A Case Study on Management of Pari Temple}

especially in Reports of Goods of Power of Use for Users of Heritage Semester, in this report types, namely equipment and machinery, buildings and buildings, and other fixed assets, in this report heritage assets are recorded in the form of units. Heritage assets in Indonesia have legal references, namely law number 10 of 2010 and PSAP 07 of 2010.

The limitation of this research is that it has only a few informants since in order to improve the effectiveness of research time, the researcher focuses more on the accounting treatment for Pari Temple as heritage assets. This research should add more informants and research objects such as buildings, museums, artifacts. Further studies are expected to Academic informants from lecturer or standard board to enrich the information of accounting treatment for heritage assets

\section{References}

Act Accounting Policy (2009). Heritage and Community Assets: Measurement of Heritage and Community Assets.

Agustini, A. T. (2011). Arah Pengakuan Pengukuran, Penilaian dan Penyajian Aset Bersejarah dalam Laporan Keuangan pada Entitas Pemerintah Indonesia (Studi Literatur). Skripsi, Universitas Jember, Jember. Retrieved from

http://repository.unej.ac.id/bitstream/handle/123456789/187/AISA\%20TRI\%20AAKT2.pdf; sequence $=1$

Anggraini, F. G. (2014). Perlakuan Akuntansi untuk Aset Bersejarah (Studi Fenomenologi pada Pengelolaan Candi Borobudur). Skripsi, Universitas Diponegoro, Semarang. Retrieved from http://eprints.undip.ac.id/42920/1/10 ANGGRAINI.pdf

Aversano, N. (2016). Heritage Assets. Springer International Publishing Switzerland. Retrieved from https://link.springer.com/referenceworkentry/10.1007\%2F978-3-319-318165 2274-1

Aversano, N. d. J. C. (2012). Governmental Financial Reporting of Heritage Assets in The Perspective of User Needs. Social Science.

Barton, A. D. (2000). Accounting for public heritage facilities - assets or liabilities of the government? Accounting. Auditing \& Accountability Journal, 13(2), 219-235. https://doi.org/10.1108/09513570010323434

Basnan, N., Salleh, M. F. M., Ahmad, A., Harun, A. M., \& Upawi, I. (2015). Challenges in accounting for heritage assets and the way forward: Towards implementing accrual accounting in Malaysia. Malaysian Journal of Society, 11, (63-73). Retrieved from https://www.semanticscholar.org/paper/Challenges-in-accounting-for-heritageassets-and-in-Basnan-Salleh/328f254e4537bc773b16a38c265f9d117abb1421

Biondi, L. \& Lapsley, I. (2014). Accounting, transparency and governance: the heritage assets problem. Qualitative Research in Accounting \& Management, 11(2), 146-164. https://doi.org/10.1108/QRAM-04-2014-0035

Darmawan, C. B., Yadnyana, I. K. \& Sudana, I. P. (2017). Menguak Perlakuan Akuntnasi Aset Bersejarah (Studi interpretif pada Museum Semarjaya Klungkung). E-Journal Ekonomi dan Bisnis Universitas Udayana. 6(5), 1785-1816. Retrieved from https://ojs.unud.ac.id/index.php/EEB/article/view/28032

Dhani, U. O., Husaini, \& Abdullah T. (2017). Peranan Balai Pelestarian Cagar Budaya (BPCB) Aceh Dalam Pelestarian Situs-Situs Bersejarah di Kota Banda Aceh Tahun 1990-2015. Jurnal Ilmiah Mahasiswa (JIM) Program Studi Pendidikan Sejarah. 2(1), 114-125. Retrieved from http://www.jim.unsyiah.ac.id/sejarah/article/download/2521/1334 
GRAP. (2012). Generally Recognised Accounting Practice: National treasury. Departement National Treasury Republic of South Africa.

Halim, A. d. M. S. K. (2014). Teori, Konsep, dan Aplikasi Akuntansi Sektor Publik, Vol. 2. Jakarta: Salemba Empat.

IPSAS. (2010). International Public Sector Accounting Standards (IPSAS) 17 Property Plant and Equipment. New York: International Federation of Accounting.

Moleong, L. ( 1993). Metodologi Penelitian Kualitatif. Bandung: Remaja Rosda Karya.

Ouda, H. A. G. T. (2014). Towards a Practical Accounting Approach for Heritage Assets: An Alternative Reporting Model for the NPM Practices. Journal of Finance and Accounting, 2(2), 29. Retrieved from https://www.researchgate.net/publication/303390426 Towards a Practical Accoun ting_Approach_for_Heritage_Assets An_Alternative_Reporting_Model_for the NP M Practices

Pallot, J. (1992). Elements of a theoretical framework for public sector accounting. Accounting, Auditting \& Accountability Journal, 5(1), 3859. Retrieved from http://www.sciepub.com/reference/48737

PSAP. (2010). Pernyataan Standar Akuntansi Pemerintahan (PSAP) Nomor 07 Tahun 2010 Tentang Aset Tetap.

Safitri, M. R., \& Indriani, M. (2017). Praktik Akuntansi untuk Aset Bersejarah Studi Fenomenologi pada Museum Aceh. Jurnal Ilmiah Mahasiswa Ekonomi Akuntansi (JIMEKA). 2(2), 1-9. Retrieved from http://www.jim.unsyiah.ac.id/EKA/article/view/2387

Sugiyono. (2009). Metode Penelitian Pendekatan Kuantitatif, Kualitatif dan R \& D. Bandung: Alfa Beta.

Suwardjono. (2010). Teori Akuntansi :Pengungkapan dan Sarana Interpretatif (Vol. 3). Yogyakarta BPFE.

Wild, S. (2013). Accounting for Heritage, Cultural, and Community Assets-Alternative Metrics from a New Zealand Maori Education Institution. AABFJ, 7(1). Retrieved from https://ro.uow.edu.au/aabfi/vol7/iss1/2/

Wulandari, D., \& Utama, A. A. G. S. (2016). Perlakuan Akuntansi untuk Aset Bersejarah: Pengakuan, Penilaian dan Pengungkapannya dalam Laporan Keuangan (Studi kasus pada Museum Anjuk Ladang Kabupaten Nganjuk). Diponegoro Journal of Accounting. 4(3), 1-11. Retrieved from https://jurnal.unej.ac.id/index.php/prosiding/article/view/3693

Yusuf. (2010). Langkah Pengelolaan Aset Daerah Menuju Pengelolaan Kenangan Daerah Terbaik. Jakarta: Salemba Empat. 